\title{
A case of witchcraft assault in early nineteenth-century England as ostensive action
}

Stephen Mitchell

In his provocatively entitled Cows, Pigs, Wars, and Witches: The Riddles of Culture, anthropologist Marvin Harris suggests a one-dimensional explanation for the witch-hunts of early modern Europe, an all-encompassing theory of class warfare manipulated by elite culture, in effect, 'the magic bullet of society's privileged and powerful classes'. Of course, the case for the marriage of anthropology and history as a means of unravelling such mysteries as the European witch-hunts has been - and was already being in the early 1970s - made by a number of scholars, and usually, although not always, brought to this question a measure of subtle and helpful insights. Confidence was high that the lessons derived from fieldwork in living traditions of witchcraft might shed light on the seemingly irretrievable historical situation of early modern Europe. Throughout much of this century, functionalist interpretations of witchcraft in non-western contexts, for example, held that concepts of witchcraft are also theories of causation - and if there is causation, then there are agents of causation, and if there are agents of causation, then such agents can be identified. This view of witchcraft as a logical cultural construct was classically formulated by Evans-Pritchard in his study of Zande witchcraft, ${ }^{1}$ in a conscious refutation of the views promoted by Lévy-Bruhl that regarded magic as unintelligible to logical thought. ${ }^{2}$ Following Evans-Pritchard's monograph, several main trends in the anthropological interpretation of witchcraft accusations evolved, neatly categorized by Max Marwick as: (1) an outlet for repressed hostility, frustration, and anxiety; (2) the means for reaffirming social norms; (3) an index of social tension in society; and (4) a measure of tense personal relationships between accuser and accused. ${ }^{3}$ While helpful, these four categories can and have been expanded and altered depending on the type of approach taken. ${ }^{4}$ Following decades of study at the structural level of society, a more dynamic, incident-specific interpretive framework emerged in the 1960s. This approach is most closely associated with Victor Turner and did much to refine, and even revolutionize the anthropologist's understanding of witchcraft, ${ }^{5}$ although not without criticism. ${ }^{6}$ 
It was at roughly this stage in the headily percolating ethnographic debate, that the observations of anthropologists were specifically turned to the historical European situation, ${ }^{7}$ and with these important developments, the study of European witchcraft changed profoundly. ${ }^{8}$

The suitability of the analogical ethnographic argument to historical western European materials, although generally well regarded, ${ }^{9}$ has not been without its difficulties. One obstacle has been the frequently insurmountable differences between the realities of highly localized observations within a small community and the uncertainties of reconstructed, region-wide events that present additional, special complications, such as the involvement of outside secular and religious authorities. An attendant difficulty has been the proliferation of theories looking to interpret the data, many of them exceedingly useful but almost always presented with a discernable quality of intellectual hegemony. Historians have certainly felt the pinch that comes with interpretations that are overly subtle or dare to rely on multiple theories for getting at some central truth, as Robin Briggs reminds us in his Witches and Neighbours. ${ }^{10}$ One evolutionary pattern that has received a measure of approbation is implicit in the works of Kieckhefer, Cohn, Klaits and others. This runs along the following lines: popular (non-elite) fears and belief systems concerning individuals capable of harmful magic fuse in the later Middle Ages and in the early modern period with elite concerns, especially those of the Church, regarding heresy and other issues, resulting in a symbiosis between elite and non-elite views, the most apparent results of which were the witch trials between 1400 and $1700 .{ }^{11}$ Following the so-called 'Enlightenment' in the eighteenth century, religious and secular authorities repudiate such belief systems, whereas non-elite views about witchcraft and evil continue into the contemporary world. Briggs accords a far smaller role to the interventions of elite culture and goes so far as to note that witchcraft beliefs may provide evidence of biologically conditioned fear of evil magic and its practitioners, and reminds us that, contra Harris and a host of others, the peasantry itself was by no means without its own active role in the process of the witch-hunts. ${ }^{12}$ And yet after several decades of concentrated debate, Macfarlane's bipartite summary of the phenomena necessary for the formation of accusations in specific instances - 'firstly, the presence of some tension or anxiety or unexplained phenomenon; secondly, the directing of this energy into certain channels' - remains a useful reminder of the basic ingredients of an accusation. ${ }^{13}$ It should be tempered though, as Ronald Hutton notes, by an 'emphasis on the need to reconstruct holistically the mental world of the participants in the trials, and a perception of the enhanced importance of folklore studies and psychology in the interpretation of the Hunt'. ${ }^{14}$ Into this brief consideration of the theories of witchcraft, and with an eye towards a better understanding of theories of causation, the relevance of Hutton's perceptive observation concerning the 'mental world' 
of the participants in witch-hunts, and the folkloric dimensions that help create and define these activities - specifically the question of ostension - I would like to insert an incident from a village in the English countryside from long after the era of the witch-hunts. ${ }^{15}$

\section{The case of Ann Izzard ${ }^{16}$}

In 1808 Ann Izzard and her husband, of Great Paxton, Cambridgeshire, were attacked in their cottage by a mob of other villagers on two successive nights. The case has maintained a certain notoriety in local tradition, and forms part of - what was once in any event - a vigorous local belief system regarding witchcraft. ${ }^{17}$ It was also a case that demanded the attention of contemporary legal authorities. According to the court documents, the case begins from this perspective when the accused residents of the village

together with divers to wit fifty other persons to the Jurors at present unknown being rioters routers and disturbers of the public peace of our said Lord the King on the eighth day of May ... with force and arms in the parish of Great Paxton aforesaid in the County aforesaid unlawfully riotously and tumultuously did assemble and gather themselves together to disturb the Peace of our said Lord the King and being so assembled and gathered together the dwelling house of Wright Izzard situate and being in the parish of Great Paxton aforesaid in the County aforesaid then and there did unlawfully riotously and riotously break and enter and the Door of the said Wright Izzard of and belonging to the said dwelling house and then and there affixed thereto and then and there being shut bolted and fastened did then and there unlawfully riotously and riotously force and break open, break to pieces and destroy And that they the said Joseph Harper Thomas Braybrook James Staughton Mary Amey Frances Amey and Alice Brown and the several other persons to the Jurors aforesaid yet unknown then and there with force and arms riotously and tumultuously did make an assault on the said Wright Izzard and also on and upon the Ann the wife of the said Wright Izzard And them the said Wright Izzard and Ann his wife in the Peace of God and our said Lord the King then and there being did beat wound and ill-treat and her the said Ann then and there with force and arms did then and there seize and drag from the Bed in which she the said Ann then and there lying and being and with Pins and other Sharp Instruments did then and there lacerate and wound the said Ann in and upon the Neck Breasts Arms Sides and different parts of the body and then and there greatly terrify and affright the said Ann and put her in great fear of the loss of her life and other wrongs to the said Wright Izzard and Ann his wife. ${ }^{18}$

In addition to the court records, we are fortunate to have the detailed, published observations of these events by Isaac Nicholson, the curate of the parish that included Great Paxton. ${ }^{19}$ The Rev. Nicholson's description of these 
assaults is much briefer than the Crown's, but also much clearer about the cause of it:

A considerable number of people assembled together, as it grew dark on Sunday evening, the eighth of May, and taking with them the young women ridiculously supposed to be bewitched, and about ten o'clock; proceeded to the cottage of Wright Izzard, which stands alone, at some distance from the body of the village. When they arrived at this solitary spot, so favourable for the execution of their villainous designs, they broke into the poor man's house, dragged his wife out of bed, and threw her naked into the yard; where, her arms were torn with pins, her head was dashed against the large stones of the causeway - and her face, stomach, and breast were severely bruised with a thick stick that served as a bar to the door. Having thus satisfied themselves, the mob dispersed. The woman then crawled into her house, put her clothes on, and went to the constable, who said, 'he could not protect her, because he was not sworn'. ${ }^{20}$

On the evening of the following day, Izzard is assaulted a second time, with the result that, again according to the court papers, the attackers

unlawfully violently and maliciously did seize and drag the said Ann from the bed in which she was then and there lying and being And with their fists did then and there strike the said Ann divers violent and grievous strokes and blows whereby the said Ann was then and there thrown and forced to and upon the ground and with certain Pins and other sharp Instruments which they the said Joseph Harper Thomas Braybrook James Staughton Mary Amey Frances Amey and Alice Brown then and there had and held in their hands unlawfully and maliciously did then and there lacerate and wound her the said Ann in and upon the Breasts and other parts of the body. ${ }^{21}$

It should be noted that neither the indictment nor the Rev. Nicholson's account appears to comprehend the reason for the violent assaults on Ann Izzard. Certainly, the Rev. Nicholson understood that it was connected with the supposed bewitchment of several young people, but would appear to believe that his flock has simply turned into a mob in order to avenge itself on Izzard. The court documents come closer when they specify that the attackers have come prepared with pins and other sharp objects with which they lacerate Izzard, 'whereby the said Ann then and there lost great quantities of Blood which ran and flowed from the breasts and body of her the said Ann and then and there suffered great pain smart and anguish'. ${ }^{22}$ It is, I submit, on the intersection of interpretations about what takes place at this juncture that the case as a whole turns. The surviving contemporary evidence - our various testimonies from elite sources - are largely deaf on this issue, although the indictment's emphasis on 'Pins and sharp Instruments' reflects the understanding the villagers themselves, attackers and attacked alike, placed on events, as I argue below. 
According to the Rev. Nicholson, the troubles of 1808 began when several young women, Alice Brown, Fanny Amey and Mary Fox, began seriatim to fall subject to 'convulsions', 'fits, weakness, and dejection' of an unknown origin and can no longer work. In an attempt to discover the cause of the troubles in the village, the father of one of the afflicted girls tries a charm. He does so on the advice of a stranger, ${ }^{23}$ who, according to the Rev. Nicholson, relates the following story:

'As sure as you are alive, Sir,' continued a man, who stood by, 'she is bewitched, and so are two other girls that live near her. There is a man in the town I come from in Bedfordshire, who was exactly like Alice Brown he could do no work, lost all his strength, and was wasting away very fast, when a person told him what was the matter with him, and how he might be cured. He filled a bottle with a particular kind of a fluid, stuffed the cork both top and bottom, with pins, set it carefully in an oven of a moderate heat, and then observed a profound silence. In a few minutes the charm succeeded; for, he saw a variety of forms flitting, before his eyes, and amongst the rest the perfect resemblance of an old woman who lived in the same parish. This was what he wanted - he was now satisfied who it was that had injured him, and that her reign would soon be over. The woman, whose figure he saw, died in a few days, and the man immediately recovered.' ${ }^{24}$

Later, Nicholson is told that the girl 'is under an ill tongue' and 'bewitched'. The following Sunday, Ann Izzard tells Nicholson that her neighbours claim to have discovered through various charms that she is a witch and blame her for the illness of the three young women. Despite Nicholson's best efforts, a frenzied state of panic eventually ripples through the parish, following a triggering event that in the minds of the villagers tips the scales in favour of the violence described by Nicholson and the court papers.

A year and three court proceedings later, nine villagers are found guilty of assaulting the couple. ${ }^{25}$ Importantly, it should be noted that the attackers do not accept that their behaviour was wrong. According to the Sussex Weekly Advertiser of 27 November 1809, one of them, Joseph Harper, testified at his trial that Ann Izzard had cried out with a voice - 'the Old Note' - just as the girls had done when they were in their fits, and one of the fathers, Thomas Brown, claimed that once his daughter had drawn blood from Ann, her fits had come to an end. ${ }^{26}$ Against this view from the participants in the attacks on the Izzards, I place part of the judge's pronouncement against the accused when they were found guilty and sentenced to various periods in gaol. It stands as an excellent reminder of just how at odds were elite and non-elite opinions about the case:

But however such an assembling of persons and their committing such assault may excite our surprise, and call our indignation; the pretence for doing it is still more extraordinary and surprising; namely, that two of you, the defendants, were under the influence of the witchcraft of the prosecutrix 
Ann Izzard, and that the torturing and drawing blood of this poor woman, was the only remedy for that witchcraft. - Such a pretence is so extraordinary, that it can hardly be used by any honest people in the present state of human knowledge in the community in which we live, when it is known by the most ignorant among us, that the law prohibits, and punishes severely, persons who shall pretend to possess the power of witchcraft, sorcery, or incantation ... In fact, the wisdom of the Legislature has declared, that such a cause as that which you have pretended to have operated upon your mind, and led to your outrageous conduct on this occasion, does not exist, and therefore you cannot stand excused by your pretence of a deluded ignorance, and it is now held out to the world that the presence of the power of witchcraft is only founded in delusion, claimed to be exercised by none but knaves, and believed by none but fools. - It was to prevent the fraud of impudent impostors practising on the folly of others, that the statute was enacted. - Indeed there is a difficulty in believing that any of you could, seriously, conceive that this poor women you so cruelly assaulted, really possessed the power of witchcraft; but that you pretended that ignorance to excuse your malice; and when we reflect on the consequence which might have followed your misconduct, the power that might have been necessary to repel your riotous behaviour to protect the public and preserve the peace, or indeed to get this poor unfortunate woman out of your power, your offence becomes a very serious one, and the more I have turned the subject in my mind since the trial, the more I am disposed to think that the pretence of your believing in the witchcraft of this poor creature, was the effect only of your malice against this individual. ${ }^{27}$

\section{The background of the assaults}

Described in 1808 as 'a small mean village' at the time of the attacks, Great Paxton consisted of 217 inhabitants living mainly in mud-walled cottages. ${ }^{28}$ Huntingdonshire was at this time in the midst of serious economic realignment, with factory labour becoming a growing source of income. ${ }^{29}$ Adding to the sense of great economic changes, the process of enclosure was under discussion for Huntingdonshire, for which it would be authorized shortly after the events of the Izzard case. In addition to the economic situation of the villagers and the major cultural changes under way in the area, what best contextualizes the events of 1808 are the personal tragedies in Great Paxton in the preceding period, calamities that outline the tension, anxiety and unexplained phenomena - to paraphrase Macfarlane's useful remark - present in Great Paxton. According to the parish records, Mary Hook, one of those imprisoned for her part in the assaults on Izzard, had lost four of her seven children at early ages, mostly under eighteen months, by the time of the attacks, and one of her three surviving children died just months afterward on 21 July $1808 .^{30}$ In fact, the parish records suggest a series of unusual deaths among the villagers. In 1799, Thomas Russel, 'Died in a fit at the 
bottom of the Hill, near the village'; in 1801, James Anvill accidentally drowned; in 1803, James Staughton, the six-year-old son of James Staughton, who will be one of those jailed for the attacks on the Izzards, 'accidentally drowned in a Pond in the Street'. Especially meaningful, in the months leading up to the assaults, we find that on 21 February 1808, Robert Emery 'aged 14: yr 3. mo. In a fit of lunacy hanged himself owing as it was thought to the loss of his sight. He had been blind something more than two months - this heavy affliction preyed upon his mind. He used to tell his father he had more upon it than he could bear.' ${ }^{31}$ It is in this context, in an atmosphere of odd deaths in a village of some 200 inhabitants, and just weeks after a young man commits suicide, that a number of other young people fall subject to fits. To the residents of Great Paxton, some evil force no doubt seemed to be abroad. For his part, the Rev. Nicholson mentions only the fits of the young women (which he is inclined to attribute to natural causes) and takes no note at all of these other factors, not even Emery's death. ${ }^{32}$

Collateral information about Izzard's reputation as a witch suggests that it was in all likelihood strong before, and not merely after the events of 1808 , and although Izzard moved out of Great Paxton, she continued to be harassed and stories about her magical powers continued to be told. One of the most striking features of the Izzard case is its similarity to other, earlier accusations of bewitchment; and as in many incidents of witchcraft accusation and persecution, while the table for such accusations is set by long-simmering troubles and reputations a lifetime in the making, the events in Great Paxton are touched off by first one and eventually several young women behaving oddly, oddly enough to bring the attention and concern of adult society to bear on their collective condition. ${ }^{33}$ When no normal medical remedy seems to have an effect, popular opinion holds that the agents of causation can be identified through special divination. It is at this point, however, that the Great Paxton case differs so sharply from earlier cases: whereas in pre-Enlightenment cases, ecclesiastical and judicial authorities joined, indeed, directed subsequent prosecution of the accused, in the Huntingdonshire of the nineteenth century, the church and the law stood firmly against belief in witchcraft. But official reactions are not fully post-Enlightenment: it should be remembered that the parish constable, an office typically held by a local farmer or other community member, refuses to give relief to Izzard following the attacks on her, with the excuse that he has not yet been sworn in. This figure more than any other, perhaps, underscores the differences between elite and non-elite assessments of the situation: despite having been chosen to represent the courts in the village of Great Paxton, the constable, coming from the village itself but importantly holding the confidence of elite society, apparently sides with the villagers' interpretations of events. ${ }^{34}$

For the villagers of Great Paxton, causation is the immediate key to solving their trouble, and they consequently undertake to find the individual 
responsible for the malefic magic in their midst, identifying Ann Izzard as the cause of their problems. At this juncture the disintegration of the witch-hunting pact between elite and non-elite is most apparent. In essence, the dilemma over which Great Paxton found itself torn in 1808 - torn along class lines - is well described by an astute conclusion drawn from an observation from the field nearly forty years ago about attitudes toward the killing of a witch: does a popular response to witchcraft represent an act of public service, or is it an attack on the very foundation of society? ${ }^{35}$ Precisely these conflicting interpretations were made of the events of 1808 by the various participants. To the villagers, the attacks on Izzard are neither illogical nor hysterical outbursts, but rather understood by the attackers to be acts of value to the community as a whole, in effect, a necessary cleansing rite. The fathers of the afflicted girls hail as a success their work to free their daughters from the evil in the village, yet the same behaviour causes the judiciary and the clergy to recoil in horror at the violence and injustice of the villagers' behaviour. To the Rev. Nicholson and the justice system, the attacks are nothing more than outrages committed against an innocent victim, acts which threaten social order as a whole, an order of which they are the most prominent representatives in the area. In the view of the elite class, the villagers are anything but pillars of society; they are nothing more than 'rioters routers and disturbers of the public peace'. ${ }^{36}$ To follow the symbiotic model noted earlier, when the synergy of witchcraft beliefs held by the elite and popular segments of society ends, the two largely go their separate ways, as the two views about what happens in Great Paxton in 1808 underscores.

\section{The assaults on Izzard as ostensive action ${ }^{37}$}

To put the Izzard case into the sort of perspective in which non-European witchcraft traditions are often assayed, the villagers held to a 'magical world view', one that is perceived by elite society then as now to be inferior with respect to both religion and to science. ${ }^{38}$ It is a world-view that does not recognize the possibility of accidents or randomness: in the 'magical world view' everything is logically connected in a chain of causation. ${ }^{39}$ The 'magical world view' provides an important perspective on the case of Ann Izzard, as the villagers remain convinced that they have behaved properly: they identify the problem, confront it and fix it. Certainly this is the interpretation reflected in the testimony of one of the participants, Thomas Brown, who maintains at the trial that the village 'remedy' has worked. One important and helpful way to understand the events of 1808-9 is to view the collective behaviour of the villagers as acts of ostension, that is, the acting out of traditional narratives - what one folklorist describes as the dramatic extension of legend complexes into real life, a factor frequently cited in the context of contemporary rumour panics. ${ }^{40}$ As has been noted of the reticulations between 
legendary beliefs, on one hand, and behaviour that helps constitute these phenomena, on the other, 'not only can facts be turned into narratives but narratives can also be turned into facts'. ${ }^{41}$ In his discussion of contemporary satanic incidents in the US, Bill Ellis argues a point that has particular relevance for the Izzard case: 'Folklorists must acknowledge that traditional narratives ... are also maps for action, often violent actions.' ${ }^{42}$ Among the villagers of Great Paxton, the assaults were considered neither violent outrages, revenge attacks nor irrational outbursts. Rather to the villagers, conditioned as they were by a unified system of witchcraft beliefs and supporting narratives, the attacks represented an appropriate remedy to their problems; their reaction was the enactment of an inherited script for a folk exorcism. It is for this reason they appeared outside the Izzard cottage armed with 'Pins and sharp Instruments', prepared to play out their parts in this serious drama by drawing blood from the person believed to be a witch. That the contours of this case were profoundly shaped, not only by the proximate events and social details within Great Paxton itself, but also by the larger native traditions of 'how to respond in the event of witchcraft', may be seen by the degree to which much of the story of 1808-9 and its subsequent life as oral history and lore in the village, is paralleled elsewhere in the corpus of English witchcraft traditions as represented in Baughman's Type and Motif-Index of the Folktales of England and North America. ${ }^{43}$ Virtually all aspects of the Izzard case - the unusual events that take place in Great Paxton, the means used to discover the malefactor, the methods employed in countering the witch's charms, how Izzard herself responds when she realizes she is thought to be the witch - are conceived, interpreted and shaped by traditional rubrics about witchcraft. ${ }^{44}$ Phatic and healing conversations using - indeed, dictated by - the narrative motifs which made up such scripts rippled through the village with the unfolding of each new event. ${ }^{45}$ It is precisely in this sense that we must understand the following episode, one of a growing number of signs that something is amiss in the village just before the assaults, of which the Rev. Nicholson reports:

On Thursday the fifth of May, Ann Izzard was at St. Neots market; and it so happened that her son, about sixteen years old, was sent the same day to St. Neots, by his master, a respectable farmer of Great Paxton, for a load of corn. When he returned, his mother and another woman accompanied him. Contrary to the better advice of her neighbour, the latter insisted upon putting a basket of grocery upon the top of the sacks of corn. One of the horses which drew the cart, was young and unmanageable, and in going down the hill which leads into the village of Paxton, by his plunging and restiveness, overturned it. By this unfortunate accident the shopkeeper's grocery was materially damaged; and, because Ann Izzard had repeatedly advised her not to put the basket upon the sacks, she charged her with overturning the cart by means of her infernal art, on purpose to spoil her 
goods. It will scarcely be credited, that in an hour after, the whole parish was in an uproar: 'She has just overturned a loaded cart, with as much ease as if it had been a spinning wheel,' was echoed from one end of it to the other. Men, women and children raised their voices, and exclaimed, 'we have now proof positive of her guilt - this last act in open day speaks for itself she is the person that does all the mischief, and if something is not done to put a stop to her baseness, there will be no living in the place." ${ }^{46}$

In this account, we see how misfortune and physics are turned by the residents of Great Paxton into marvels and signs that conform to traditional motifs (Witch bewitches wagon; Witch upsets loads of hay on level ground), shaping the accusations that follow. ${ }^{47}$ Macfarlane's model of pre-existing tensions being channelled in a certain direction in the aftermath of an incendiary event aptly accounts at one level for events in Great Paxton. ${ }^{48}$ But that explanation is considerably enhanced when we recognize the degree to which this channelling represents a manifestation of complex traditional codes of behaviour concerning witchcraft.

Further evidence of the reticulation between (1) beliefs about appropriate responses to witchcraft, (2) witchcraft narratives in general, (3) the specific actions taken in the Izzard case and (4) the stories about this incident, is providentially provided for us through a competition for Huntingdonshire village stories organized by the Women's Institute in 1935. One entry in the resulting manuscript, offered by the wife of a descendant of one of Izzard's persecutors, gives us new insights into how the story has been remembered within the village. ${ }^{49}$ Izzard is described as having 'a good knowledge of herbs and simples', making her a feared witch figure in the community. But the stories also associate Izzard with an array of behaviours we do not have knowledge of elsewhere, either in the Rev. Nicholson's reports or the court documents. All of these stories parallel aspects of English witchcraft tradition: Izzard is said, for example, to have bewitched the wife of her creditor, the innkeeper and grocer, 'making her go through all sorts of queer antics, even to dancing on the tea table among the cups and saucers' (Magic dancing; Enchanted persons dance until released; Witch causes innkeeper to dance in revenge for overcharging, Witch torments person by making him act in a ridiculous manner). ${ }^{50}$ It sounds like a reworking of the wagon episode, in which the shopkeeper's groceries are ruined. 'Nanny' Izzard is also reported to have gone to local farmers, demanding butter, 'and if people refused to let her have it, she would put her hand in the churn so that it was "witched" and refused to turn any more. One day, the farmer, Mr Bidwell, put a red hot poker into the churn, so when poor old Nanny tried to do the bewitching she got badly burnt' (Breaking spell on cream that refuses to become butter by putting hot iron in the cream, thus burning the witch; Breaking spell on cream by putting hot poker in the cream; Hot iron put into churn). ${ }^{51}$ Not only were the events of 1808 shaped by witchcraft narratives, but the subsequent 'defence' of the villagers' collective 
behaviour, specifically among the families of those most responsible, is similarly moulded by such motifs.

The case of Ann Izzard is hardly a particularly severe instance among post-Enlightenment witchcraft episodes. Yet had it taken place two hundred years earlier, elite English institutions might well have agreed with the villagers' understanding of their situation and joined them in the persecution. By the early nineteenth century, however, the symbiotic relationship between elite and non-elite sections of society where witchcraft is concerned has changed, and the differing views of magic, evil and causation held by the authorities and by those over whom they had dominion play out in significantly different ways. As Trevor-Roper noted, the eradication of such a belief system could not take place in isolation, but only when the total environment that supported it has changed. ${ }^{52}$ Such a transformation had indeed occurred in elite society by the nineteenth century, as we are reminded when the judge berates the defendants at the trial by calling their defence - that the girls were 'under the influence, the sorcery and witchcraft of the prosecutrix' 'absurd' and an 'impossible pretence'. ${ }^{53}$ But a very different view was held among non-elites, as the behaviour of the villagers in the Izzard case usefully reminds us. The result of this hybridized situation, with institutional opinion totally transformed, but village-level perspectives largely unchanged, did not in the end spare Ann Izzard pain, humiliation and actual harm, although it very probably spared her life. Moreover, it is a case that highlights how profoundly ingrained traditional views remained among the populace as a whole, and how quickly such views could be turned into ostensive action.

\section{Notes}

1 I take this opportunity to express my heartfelt thanks to the many librarians, churchwardens, local historians and pub owners (and customers) in the Great Paxton area for their assistance in researching this essay; I am particularly obliged to Alan Akeroyd and his colleagues at the County Records Office, Huntingdon. E. E. EvansPritchard, Witchcraft, Oracles and Magic Among the Azande (Oxford, 1937), p. 387. See, however, Evans-Pritchard, Theories of Primitive Religion (Oxford, 1965), p. 114: 'The so-called functional method was too vague and too slick to persist, and also too much coloured by pragmatism and teleology. It rested too much on a rather flimsy biological analogy.' Nevertheless, it can be little doubted that Evans-Pritchard's Witchcraft, Oracles, and Magic Among the Azande came to be associated largely with such homeostatic concepts as the patterned expression of tension within the community, the normative effect of witchcraft beliefs on behaviour, and so on, and gave rise to a number of works on African witchcraft which took this view as a starting point.

2 In discussing sympathetic magic, for example, Lévy-Bruhl remarked, 'en créant entre eux et lui un lien, inintelligible sans doute pour la pensée logique, mais conforme à la loi de participation qui régit la mentalité prélogique et ses représentations collectives': Lucien Lévy-Bruhl, Les fonctions mentales dans les sociétés inférieures (3rd edn, Paris, 1918), p. 350. The italics are mine.

3 Max Marwick, 'The Study of Witchcraft', in A. L. Epstein (ed.), The Craft of Social 
Anthropology (New York and London, 1967), pp. 237-40. See also Marwick, 'Witchcraft as a Social Strain-Gauge', in Max Marwick (ed.), Witchcraft and Sorcery (London, [1964] 1982), pp. 300-13.

4. Alan Macfarlane for example, categorized anthropological approaches as: (1) 'witchcraft as explanation', (2) 'the function of witchcraft as a release of tension', (3) 'witchcraft and the social structure', (4) 'witchcraft and social control' and (5) 'westernization and witchcraft': Macfarlane, Witchcraft in Tudor and Stuart England: A Regional and Comparative Study (London, [1970] and Prospect Heights, 1991), pp. 240-53. Tamara Multhaupt organizes these approaches to African witchcraft into historical and theoretical categories: missionary and other colonial views; LévyBruhl's concern with rationality versus irrationality; and so on: Multhaupt, 'Sozialanthropologische Theorien über Hexerei und Zauberei in Afrika', Anthropos 82 (1987) 445-56. To these approaches one would necessarily want to add emerging methodologies, such as the growing number of feminist and other gendered approaches. See, for example, Ingrid Ahrendt-Schulte, 'Hexenprozesse als Spiegel von Alltagskonflikten', in Sönke Lorenz and Dieter R. Bauer (eds), Hexenverfolgung. Beiträge zur Forschung (Würzburg, 1995), pp. 347-58; Diane Purkiss, The Witch in History (London, 1996); Marianne Hester, Lewd Women and Wicked Witches (London, 1992).

5 See Victor Turner, 'Witchcraft and Sorcery: Taxonomy Versus Dynamics', in idem, Forest of Symbols (Ithaca and London, [1964] 1967), pp. 112-27. Turner's review article of Middleton and Winter 1963, in which he pursues the question, 'What bearing has a method of sociological analysis on the study of witch beliefs?' (p. 118), argues in favour of social interactionism over a more static interpretation of witchcraft. See also Victor Turner, Schism and Continuity in an African Society (Manchester, [1957] 1972), pp. 148-53.

6 See William Arens, 'Taxonomy versus Dynamics Revisited: The Interpretation of Misfortune in a Poly-Ethnic Community', in Ivan Karp and Charles S. Bird (eds), Explorations in African Systems of Thought (Bloomington, 1980), pp. 165-80.

7 The most prominent signs of this new symbiosis were Keith Thomas's Religion and the Decline of Magic (London, 1971) and Macfarlane, Witchcraft. Mary Douglas also indicates this sea change: 'Historians and anthropologists have a common interest in the subject of witchcraft, but until very recently their outlooks have diverged ... Now this difference is being narrowed: the historians who have contributed to this volume have succeeded in delving into material very comparable to that used by anthropologists and the latter are gradually improving the time-scale of their observation. The moment has come for a survey of the subject': Douglas (ed.), Witchcraft Confessions and Accusations (London, 1970), p. xiii.

8 This paradigm shift is neatly dated by Wolfgang Behringer to the change in 1974 in the Encyclopaedia Britannica: Behringer, 'Witchcraft Studies in Austria, Germany and Switzerland', in Jonathan Barry, Marianne Hester and Gareth Roberts (eds), Witchcraft in Early Modern Europe (Cambridge, 1996), pp. 66-7. See also the overviews offered by H. C. Erik Midelfort, 'Recent Witch Hunting Research, or Where Do We Go From Here?', Paper of the Bibiliographical Society of America 62 (1968) 373-420; Jens Christian and V. Johansen, 'Tavshed er guld ... En historiografisk oversigt over amerikansk og europæisk heksetros-forskning 1966-81', Historisk Tidsskrift 81, 2 (1982) 401-23.

9 See the contributions in Douglas, Witchcraft Confessions.

10 See Robin Briggs, Witches \& Neighbours (London, 1996), p. 397: 'There are indeed historians who claim that there is something illegitimate about offering multiple explanations for simultaneous occurrences.'

11 Joseph Klaits, Servants of Satan: The Age of the Witch Hunts (Bloomington, 1985); 
Richard Kieckhefer, European Witch Trials: Their Foundations in Popular and Learned Culture, 1300-1500 (Berkeley and Los Angeles, 1976); Norman Cohn, Europe's Inner Demons: An Inquiry Inspired by the Great Witch-Hunt (London, 1975).

12 See Briggs, Witches, p. 394: 'Witchcraft may therefore be a phenomenon we are predisposed to suspect, a psychic potential we cannot help carrying round within ourselves as part of our long-term inheritance.'

13 Macfarlane, Witchcraft in Tudor and Stuart England, p. 231.

14. Ronald Hutton, review of Diane Purkiss's The Witch in History: Early Modern and Twentieth-Century Representations. See 'Reviews in History', Institute of Historical Research website: www.history.ac.uk/reviews/paper/hutton.html.

15 The importance of post-Enlightenment cases has been highlighted in Gustav Henningsen, 'Witch Persecution after the Era of the Witch Trials: A Contribution to Danish Ethnography', Arv 44 (1988; first published in Danish in 1975) 103-53; Henningsen, 'Das Ende der Hexenprozesse und die Forsetzung der populären Hexenverfolgung', in Sönka Lorenz and Dieter R. Bauer (eds), Das Ende der Hexenverfolgung (Stuttgart, 1995), pp. 315-28; Willem de Blécourt, 'On the Continuation of Witchcraft', in Barry et al., Witchcraft in Early Modern Europe, pp. 335-52; Owen Davies, Witchcraft, Magic and Culture 1736-1951 (Manchester, 1999).

16 For a fuller treatment of the details of the case, its participants, and their situations see Stephen A. Mitchell, 'Witchcraft Persecutions in the Post-Craze Era: The Case of Ann Izzard of Great Paxton, 1808', Western Folklore 59 (2000) 304-28. The present article builds on and extends the arguments, especially the relationship between the historical events and the subsequent narratives about them. See also Davies, Witchcraft, Magic and Culture, pp. 49-50, 111-12 and 197-8.

17 The area is famously associated with witchcraft. For early modern examples see C. L'Estrange Ewen, Witchcraft and Demonianism (London, [1933] 1970), pp. 169-73, 454, 461. For more recent reports see Mitchell, 'Witchcraft Persecutions'.

18 Public Record Office (hereafter PRO), London, KB 11/66 (1), St Hilary 1809, \#36 'c'.

19 Isaac Nicholson, A Sermon against Witchcraft: Preached in the Parish Church of Great Paxton, in the County of Huntingdon, July 17, 1808. With a Brief Account of the Circumstances which Led to Two Atrocious Attacks on the Person of Ann Izzard, as a Reputed Witch (London, 1808); Nicholson, An Abstract of the Proceedings had against Joseph Harper, James Staughton, Thomas Braybrook, Mary Amey, Fanny Amey, Alice Browne, Edward Briers, Mary Hook, and Mary Fox, for Assaulting Ann Izzard of Great Paxton, in the County of Huntington, on the 8th and 9th of May, 1808, under the Pretence of her being a Witch (London, 1810).

20 Nicholson, A Sermon Against Witchcraft, pp. vii-viii.

21 PRO, KB 11/66 (1), St Hilary 1809, \#36 'c'.

22 PRO, KB 11/66 (1), St Hilary 1809, \#36 'c'.

23 The role this stranger plays suggests that he might have been a cunning-man brought in for the purpose of helping in precisely this way. See Davies, Witchcraft, pp. 214-29.

24. Nicholson, A Sermon Against Witchcraft, pp. ii-iii.

25 The cases are removed from the lower courts by writs of certiorari (PRO, KB 11/66 (1), St Hilary 1809, \#36 'a' and \#37 'a'), and kept within the purview of the King's Bench. The defendants are charged both there and in the indictments themselves with 'Riots and Misdemeanours'. Importantly, the facts presented by the Crown (PRO, KB 11/66 (1), St Hilary 1809, \#36 'c' and \#37 'c') tally neatly with the version given by the Rev. Nicholson, without mentioning witchcraft.

26 Quoted in Mike Stephenson, 'The Story of Ann Izzard - Retold', The Huntsman: The Journal of the Huntingdonshire Family History Society 16 (1993) 18.

27 Nicholson, Abstract of the Proceedings, pp. 9-10. 
28 E. W. Brayley and John Britton, Historical Description of the County of Huntingdon (London, 1808), pp. 572-3.

29 Rose Young, St Neots Past (Chichester, 1996), p. 81.

30 The Register Book of Great Paxton 1702-1807 (County Record Office, Huntingdon, $2685 / 1 / 2)$.

31 The Register Book of Great Paxton 1702-1807 (County Record Office, Huntingdon, 2685/1/2).

32 The Rev. Nicholson's role in these events is complex, and I note that he may have pursued a personal agenda in his writings. Although I continue to regard his pamphlets as the most important testimony we have to events in Great Paxton, I recognize that they are anything but a mirror-like reflection of historical reality.

33 See Davies, Witchcraft, p. 197.

34. See Davies, Witchcraft, pp. 111-12, on the ambiguous and often conflicted situation of the constables.

35 'The problem of social order rests on the consensual meshing of public opinion about an act of violence which is either a favour to the society as a whole, or the most flagrant violation of its moral equilibrium': Manning Nash, 'Witchcraft as Social Process in a Tzeltal Community', in John Middleton (ed.), Magic, Witchcraft and Curing (Garden City, [1961] 1967), p. 128.

36 PRO, London, KB 11/66 (1), St. Hilary 1809, \#36 'c'.

37 Within folklore, the term 'ostension' is most directly borrowed from the field of semiotics, notwithstanding its venerable use in other fields. The meaning of the word - 'the act of showing; manifestation; revealing; appearance; display; monstrance' and its etymology (ostendere 'to show') underscore its relevance to the sort of situation under discussion.

38 See the encompassing and synthetic treatment of this thorny issue in Stanley Tambiah, Magic, Science, Religion, and the Scope of Rationality (Cambridge, 1990), pp. 1-15.

39 As Wax and Wax note, "We think of ourselves as the believers in causal law and the primitive as dwelling in a world of happenstance. Yet, the actuality is to the contrary: It is we who accept the possibility and logic of pure chance, while for the dweller in the magical world, no event is "accidental" or "random," but each has its chain of causation in which Power, or its lack, was the decisive agency': Rosalie Wax and Murray Wax, 'The Magical World View', Journal for the Scientific Study of Religion 1 (1962) 183. It is, of course, exactly the exploration of this point that is at the heart of Evans-Pritchard, Witchcraft, Oracles.

40 Bill Ellis, Aliens, Ghosts, and Cults: Legends We Live (Jackson, Mississippi, 2001), p. 41. With respect to the applicability of 'ostension' and 'ostensive action' to folkloristics, see Linda Dégh and Andrew Vázsonyi, 'Does the Word "Dog" Bite? Ostensive Action: A Means of Legend-Telling', Journal of Folklore Research 20 (1983) 5-34; Gary Alan Fine, 'Redemption Rumors and the Power of Ostension', Journal of American Folklore 104 (1991) 179-81; Bill Ellis, 'Death by Folklore: Ostension, Contemporary Legend, and Murder', Western Folklore 48,1 (1989) 201-20; idem, Raising the Devil: Satanism, New Religions and the Media (Lexington, 2000), pp. 204, 226, 236, 286-7; idem, 'Ostension as Folk Drama', in Aliens, Ghosts, pp. 165-85.

41 Dégh and Vázsonyi, 'Does the Word "Dog” Bite?', 29.

42 Ellis, 'Death by Folklore', 218.

43 Ernest Warren Baughman (ed.), Type and Motif-Index of the Folktales of England and North America, Indiana University Publications, Folklore series 20 (The Hague, 1966).

44. Among the motifs connected with the Izzard case are the following: D1741.2.1 Drawing witch's blood annuls her spells; G263.4.2 Witch causes victim to have fits; G265.8.3.2 Witch bewitches wagon; G265.8.3.2(d) Witch upsets loads of hay on level ground; 
G257.1(d) Boiling needles or pins forces witch to reveal herself; G271.4.1(h) Breaking spell by boiling victim's urine; G271.4.1(le) Breaking spell on person by putting quart bottle of pins by the fire; G273.6 Witch rendered powerless by drawing blood from witch; $\mathrm{H} 234$ Weighing witch against Bible. For a full and detailed list see Mitchell, 'Witchcraft Persecutions'.

45 The phrase 'phatic communion' was coined by Malinowski to describe language's role in promoting social solidarity and reinforcing the hierarchies within the group. See Bronislaw Malinowski, 'The Problem of Meaning in Primitive Languages', in C. K. Ogden, I. Richards anf J. Postgate (eds), The Meaning of Meaning: A Study of the Influence of Language upon Thought and of the Science of Symbolism (London and New York, 1923), pp. 451-510. The sense of 'phatic communion' has been extended to include, as I intend it here, a broad range of social, as opposed to directly informational communications.

46 Nicholson, A Sermon Against Witchcraft, pp. vi-vii.

47 Baughman, Type and Motif-Index, G265.8.3.2 and G265.8.3.2(d).

48 Macfarlane, Witchcraft, p. 231.

49 Huntingdonshire Federation of Women's Institutes, c. 1935, Tales from Hunts. Villages (bound, typed manuscript). See also C. F. Tebbutt, Huntingdonshire Folklore (St Neots, 1952), p. 32; and idem, Huntingdonshire Folklore, 2nd edn, Friends of the Norris Museum Occasional Publications 4 (St Ives, 1984), pp. 82-3.

50 Baughman, Type and Motif-Index, D2174, D2174(c) and G269.21.

51 Baughman, Type and Motif-Index, G271.4.1(k), G271.4.1(kc) and D2084.2(dd).

52 Trevor-Roper, European Witch-Craze, p. 105.

53 Nicholson, Abstract of the Proceedings, p. 7. 